\title{
New Energetic Materials Derived from Pentaerythritol, Diethanolamine, and Chloramphenicol
}

\author{
Miguel Ángel Romero* \\ 7 Norte 623, Tehuacán, Puebla, Mexico 75730.drmiguelromero@yahoo.ca
}

Received October $3^{\text {rd }}$, 2013; Accepted January $17^{\text {th }}, 2014$

\begin{abstract}
Four new compounds with potential use as low-sensitivity secondary explosives were prepared from readily available and inexpensive starting materials: pentaerythritol, diethanolamine, and chloramphenicol. Experimental and theoretical properties for each new compound are described, as well as their potential use as energetic materials.

Key words: Energetic materials, synthesis, secondary explosives, oxygen deficiency, detonation velocity, pentaerythritol, diethanolamine, chloramphenicol.
\end{abstract}

\section{Introduction}

The role that energetic materials (EMs) have played in the development of humankind is undeniable. While great works in mining, engineering and industry would not have been possible without EMs in the form of explosives, propellants and pyrotechnics, great harm and suffering has been inflicted by their senseless and terrifying use as lethal weapons in war and terrorism. Currently there is great interest in development of novel EMs which shows specific improvements in physical and chemical properties for each of their diverse applications. These improved EMs, apart from their use in the military arena, are required in diverse civil and industrial endeavors, such as microsoldering [1], diamond synthesis [2], and the creation of pulse detonation iterative devices [3], to name just a few of a great variety of modern applications.

For EMs classified as secondary explosives desirable properties include relative insensitivity to friction and/or impact, efficient and inexpensive synthesis, thermal stability, high density and detonation velocity, as well as compatibility with additives and other explosives. The ideal EMs together with their detonation products would exhibit low toxicity and would be environmentally innocuous. It is also important to consider as key aspects of their production: long shelf life, low static discharge sensitivity, appropriate oxygen balance, appropriate melting points (in the case where solids are desired), and appropriate detonation velocities. A number of excellent contemporary accounts outline these and other fundamental aspects of explosives and EMs [4].

\section{Results and Discussion}

In an attempt to generate easily obtainable insensitive secondary explosives a number of compounds were prepared using only readily available and inexpensive materials, and without
Resumen. Se describe la preparación de cuatro nuevos compuestos con uso potencial como explosivos secundarios de baja sensibilidad. Los materiales de partida, baratos y asequibles, son el pentaeritritol, la dietanolamina, y el cloranfenicol. Se describen algunas de las propiedades experimentales y teóricas de los compuestos preparados, así como su uso potencial como materiales energéticos.

Palabras clave: Materiales energéticos, síntesis, explosivos secundarios, deficiencia de oxígeno, velocidad de detonación, pentaeritritol, dietanolamina, cloranfenicol.

the need of sophisticated equipment, inert atmospheres, or expensive catalysts. Precursors to the EMs prepared were chosen for either their multifunctionality, presence of explosophoric moieties, or relative inexpensiveness and ready availability. Starting materials include pentaerythritol, a paint additive, PVC stabilizer and antioxidant component; 3, 5-dinitrobenzoyl chloride, a derivatizing agent formerly used much in the characterization of organic compounds by melting point determination [5]; diethanolamine (DEA), a surfactant and corrosion inhibitor and a precursor to several cosmetic and shampoo precursors; and chloramphenicol (D-(-)-threo-2,2-dichloro- $N$-[1,3-dihydroxy-1-(4-nitrophenyl)propan-2-yl]acetamide), a widely used bacteriostatic antimicrobial which is both inexpensive and easily manufactured. Table 1 provides the structure together with the physical and theoretical data for each of the compounds (1-4) prepared.

Detonation velocities (D) [6a] for compounds 1-4 were calculated using the Rothstein and Petersen method [6 b,c] and include a maximum estimated deviation of $4 \%$ between the calculated and experimental values as tested by the authors. Theoretical densities were calculated using the $\mathrm{ACD} / \mathrm{Labs}$ program [7]. A very informative account on the calculation of density and detonation properties of energetic compounds containing diverse arrays of $\mathrm{C}, \mathrm{H}, \mathrm{O}, \mathrm{N}$, and $\mathrm{F}$ atoms was previously published in this journal by R. L. Willer [6d].

\section{Preparation of Compounds 1-4}

Compound 1 ([1,3-bis(3,5-dinitrobenzoyloxy)]-2,2-bis(3,5-din itrobenzoyloxymethyl)propane) was readily prepared in good yield by exhaustively acylating pentaerythritol (5) with 3, 5dinitrobenzoyl chloride $(3,5$-DNBC) in the presence of triethylamine and DMAP as catalyst, as shown in Scheme 1.

This compound was isolated as an amorphous white solid with a relatively high melting point (m.p. $=224-225^{\circ} \mathrm{C}$ ) and a low degree of solubility in common organic solvents. It was, 
Table 1. Selected experimental and theoretical properties for compounds 1-4.

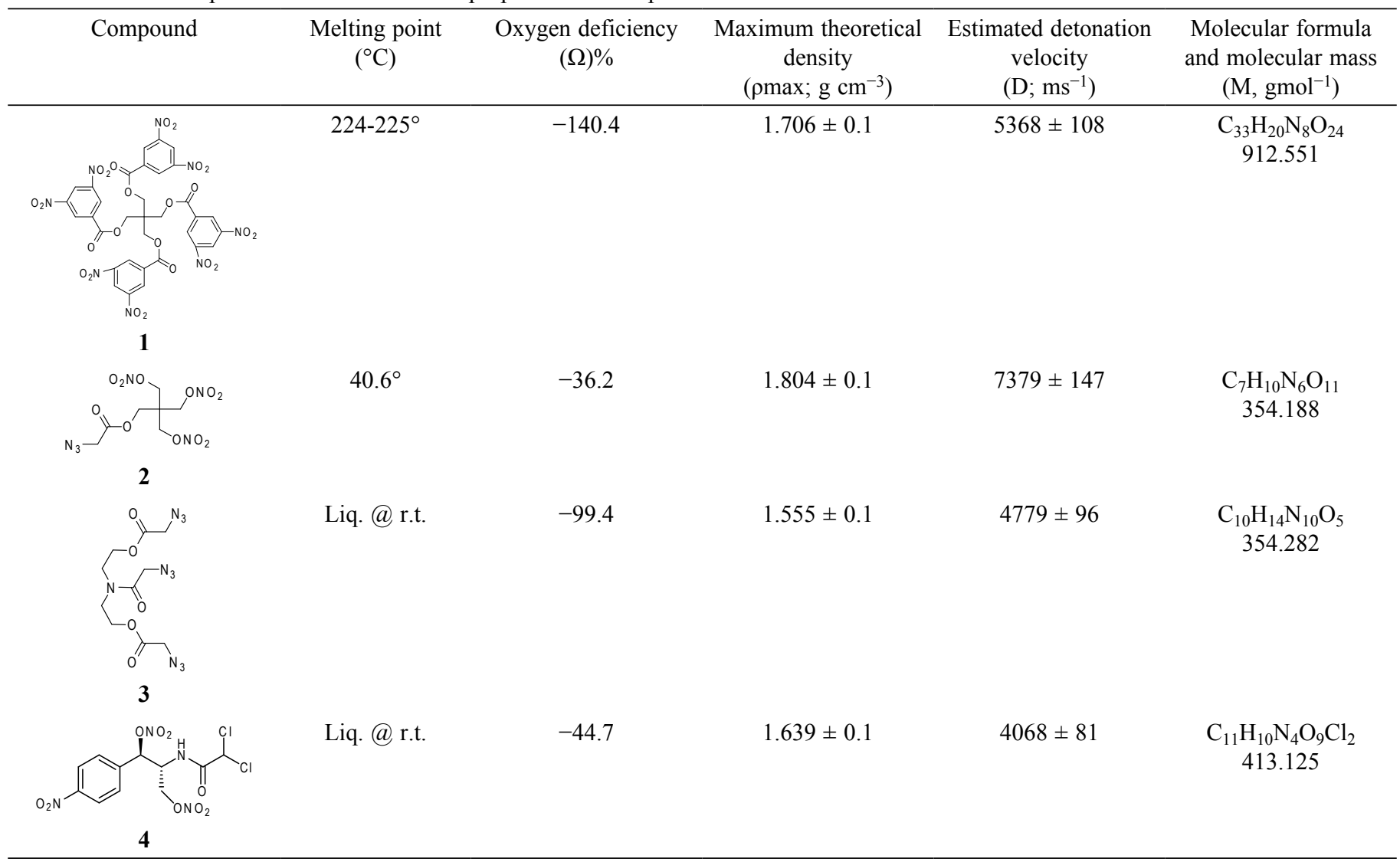

however, sparingly soluble in acetone and soluble in acetonitrile, DMF and DMSO. This compound bears a negative oxygen balance of $\Omega=-140.4 \%$, a maximum theoretical density of $1.706 \mathrm{~g} \mathrm{~cm}^{-3}$, and a calculated maximum detonation velocity $\mathrm{D}$ $=5368 \pm 108 \mathrm{~m} \mathrm{~s}^{-1}$. The oxygen balance of any organic explosive compound indicates the degree to which it can self-oxidize in a combustion reaction. This is crucial when dealing with explosives as a zero oxygen balance indicates that the compound can be fully oxidized, as desired. A negative oxygen balance indicates that there will be a lack of oxygen and consequently the self-sustaining oxidation of a particular explosive will be incomplete. Detonation velocity provides an indication of a material's relative power of detonation and shattering effect

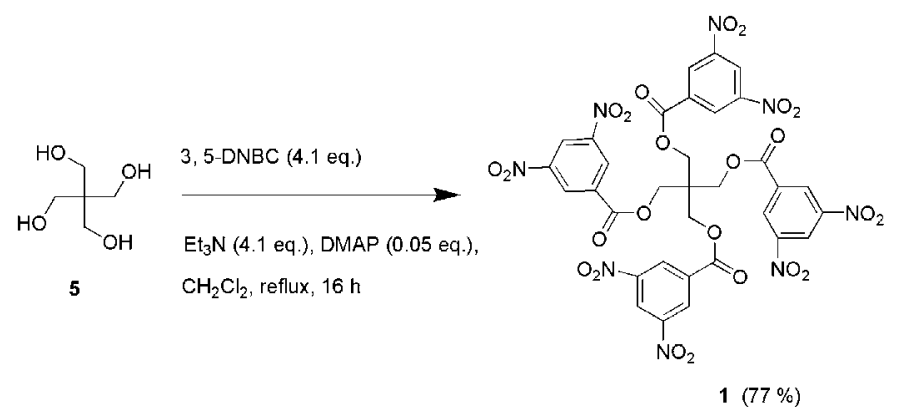

Scheme 1. Preparation of polynitrated tetraester 1. and describes the speed at which the shock wave front travels through the explosive. The detonation velocity of an explosive is directly related to the density of the material [4].

In the field of EMs an intriguing and recent area of research is the synthesis of compounds bearing a variety of explosophoric functions within the same molecule [8]. Herein we report the preparation of compound $\mathbf{2}$, a trinitrate ester that incorporates also an alkyl azide function within the same molecule. It would be interesting to determine whether compounds bearing mixed functionality such as $\mathbf{2}$ lie somewhere between their monofunctional parent compounds in terms of their energetic properties. In terms of detonation velocity this seems to be the case for compound 2, which has $\mathrm{T}_{\mathrm{dec}}=197.5^{\circ} \mathrm{C}$, maximum calculated density of $1.80 \mathrm{~g} / \mathrm{cm}^{3}$, and $\mathrm{D}_{\text {calc }}=7379 \mathrm{~ms}^{-1}$, whereas the all-nitrate ester (PETN) has $\mathrm{T}_{\mathrm{dec}}=202{ }^{\circ} \mathrm{C}, \mathrm{D}=8400 \mathrm{~ms}^{-1}$ (at maximum density $1.77 \mathrm{~g} / \mathrm{cm}^{3}$ ), and impact sensitivity of $3 \mathrm{Nm}$. The known all-azidoacetate analogue (pentaerythritol tetrakis (azidoacetate); PETKAA) has $\mathrm{T}_{\mathrm{dec}}=234{ }^{\circ} \mathrm{C}, \mathrm{D}_{\text {calc }}=5167 \mathrm{~ms}^{-1}$, density of $1.34 \mathrm{~g} / \mathrm{cm}^{3}$, and impact sensitivity $60 \mathrm{Nm}$ ). [9].

Whenever one is dealing with organic azides it is important to first determine what the appropriate level of caution should be for any particular material one is attempting to handle. The "azide golden rule" is most helpful as it establishes that covalently-bound organic azides may be handled with relative safety only if the number of nitrogen atoms within the molecule is less than the number of carbon atoms. In addition to this rule one must also consider the dictum that it is relatively safe to handle 
these compounds if the ratio of the sum of oxygen and carbon atoms divided by the number of nitrogen atoms is greater than 3 [10]. Compound 2 therefore would be considered to fall just within the limit of safety since the $(\mathrm{C}+\mathrm{O}) / \mathrm{N}$ ratio is exactly 3 . Scheme 2 depicts the sequence used for the preparation of compound 2.

PETRIN (6) is a precursor to a number of possible EMs. It was previously isolated as a side-product in the preparation of PETN [11] and is a known vasodilator with a mode of action similar to that of nitroglycerine [12]. The acylation of $\mathbf{6}$ with chloroacetyl chloride (CAC) proceeds in 94\% yield. An optimal yield could be obtained when a mixture of alcohol 6, DMAP, and $\mathrm{Et}_{3} \mathrm{~N}$ in dichloromethane was added to an ice-cold solution of CAC in the same solvent. The resulting oily compound 7 was isolated and purified by column chromatography. Reaction of 7 with a small excess of sodium azide in acetonitrile in the presence of a small amount of potassium iodide gave compound $\mathbf{2}$ as a white solid (m.p. $50.6^{\circ} \mathrm{C}$ ) in $93 \%$ yield after purification by column chromatography. Oxygen deficiency for this compound is $\mathbf{\Omega}=-36.2 \%$, and its calculated detonation velocity $\mathrm{D}=7379$ $\mathrm{m} \mathrm{s}^{-1}$. This $\mathrm{D}$ value is comparable to Pentolite, a well-known 1:1 PETN-TNT mixture with $\mathrm{D}=7530 \mathrm{~m} \mathrm{~s}^{-1}$. Compound 2 exhibits relative thermal stability, its DSC plot indicates m.p. 40.6 ${ }^{\circ} \mathrm{C}$ and a decomposition temperature $\left(\mathrm{T}_{\mathrm{dec}}\right)$ of $197.5^{\circ} \mathrm{C}$ (single transition). Compound 2, an analogue of the well-known secondary explosive PETN has a wider range of thermal stability in the liquid phase than the parent PETN (m.p.PETN $142.9^{\circ} \mathrm{C} ; \mathrm{T}_{\text {dec. }}$. PETN $202{ }^{\circ} \mathrm{C} ; \Delta \mathrm{T}_{\mathrm{m} \text {-dec }}=59.1^{\circ}$ [13]; versus $\Delta \mathrm{T}_{\mathrm{m}-\mathrm{dec}}=156.9^{\circ}$ for compound 2). The low melting point exhibited by compound 2 as well as its wide stability range as a liquid would render it suitable for casting with other low melting point EMs. PETN, in its pure form, is very sensitive to friction and impact and for this reason it is usually handled as phlegmatized material [14]. As an analogue of PETN compound 2 displays similar detonation properties but has a higher oxygen deficiency (PETN being $26.1 \%$ less deficient), and would therefore be expected to be less sensitive to friction and impact than its parent compound. Further studies are required to assess the matter.

Diethanolamine-derived compounds DINA (dinitroxydiethyl nitramine, 8) [15]; and DNAN (dinitroxydiethylamonium nitrate, 9) (Figure 1) are important and well-known EMs [16].

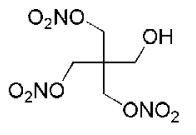

6

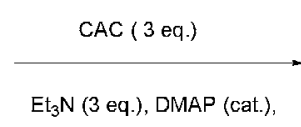

$\mathrm{CH}_{2} \mathrm{Cl}_{2}, 0^{\circ} \mathrm{C}$, then reflux $1 \mathrm{~h}$, then r.t., $2 h$.

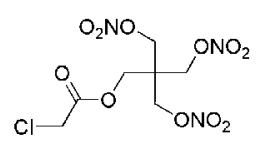

$7(94 \%)$
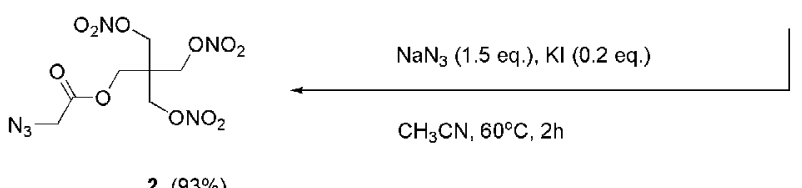

$2(93 \%)$

Scheme 2. Preparation of azidoester 2.
8
$\mathrm{O}_{2} \mathrm{NO} \sim \underset{\substack{1 \\ \mathrm{NO}_{2}}}{\mathrm{~N}} \mathrm{ONO}_{2}$

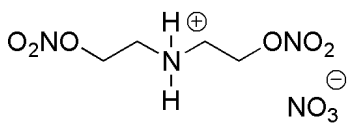

9
Fig 1. Diethanolamine-derived energetic materials DINA (9) and DNAN (10).

In order to prepare analogous materials to 8 and $\mathbf{9}$, diethanolamine 10 was subjected to exhaustive acylation with CAC, followed by nucleophilic substitution of trichloride 11 to produce the desired triazide 3 in excellent yield (Scheme 3).

In spite of the fact that both DMF and DMSO are more commonly used for azide-halogen exchange, acetonitrile was found to be practically a more convenient solvent for the transformation of $\mathbf{1 1}$ into $\mathbf{3}$. As triazide $\mathbf{3}$ falls out of the range of safety according to the azide rule and has a $(\mathrm{C}+\mathrm{O}) / \mathrm{N}$ ratio of only 1.5 , it was treated with extreme caution. Compound $\mathbf{3}$ was never heated beyond room temperature and all fraction collection and solvent removal during reaction workup was performed under a stream of dry air. Column chromatography gave triazide $\mathbf{3}$ as viscous yellow oil. When neat 3 was flame-tested with a platinum wire a slight detonation occurred. In contrast compounds $\mathbf{1}, \mathbf{2}$ and $\mathbf{4}$ exhibited mere deflagration under the same conditions. Calculations for triazide $\mathbf{3}$ give an oxygen deficiency $\boldsymbol{\Omega}$ $=-99.4 \%$ and a detonation velocity $\mathrm{D}=4779 \mathrm{~m} \mathrm{~s}^{-1}$. This value for $\mathbf{D}$ is comparable to that exhibited by compounds such as acetone peroxide and ammonium nitrate.

Compound 4, the last member in this series was prepared by directly nitrating the well-known antibiotic chloramphenicol (12) [17]. The molecular structure for this compound shows a high degree of functionalization including an explosophoric aromatic nitro group as well as primary and secondary alcohol moieties which are both capable of being nitroesterified. Compound 4 was obtained in excellent yield as outlined in Scheme 4.

Optimum yields were achieved by performing the nitration reaction using a mixture of nitric $(67 \%)$ and concentrated (98\%) sulfuric acids. Solid chloramphenicol was added while vigorously stirring the ice-cold mixture as a two-phase system with dichloromethane as a product scavenger. Compound $\mathbf{4}$ was isolated as viscous light yellow oil that was obtained in fair purity without recourse to column chromatography. This product is highly soluble in most common organic solvents and

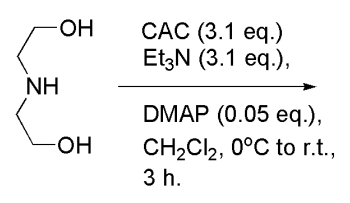

10

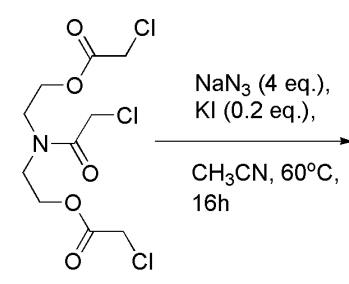

$1183 \%$

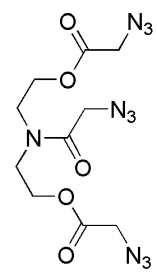

$395 \%$
Scheme 3. Preparation of triazide 3 from diethanolamine (10). 


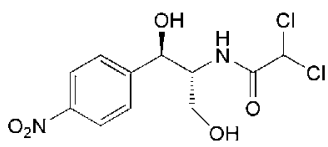

12

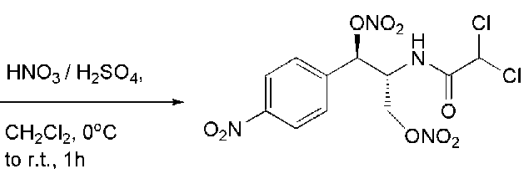

$499 \%$
Scheme 4. Nitration of chloramphenicol (12).

could be considered for use as a potential plasticizer for diverse EMs. Oxygen deficiency for compound $\mathbf{4}$ is $\Omega=-44.7 \%$, with a calculated detonation velocity of $\mathrm{D}=4068 \mathrm{~m} \mathrm{~s}^{-1}$.

\section{Concluding Remarks}

The preparation and characterization of four novel energetic compounds with potential use as high-explosives or additives for secondary explosive formulations is described. The preparation procedures used are straightforward and require few synthetic steps. The prepared compounds 1-4 exhibited calculated detonation velocities ranging from 4068 to $7379 \mathrm{~m}$ $\mathrm{s}^{-1}$. Compound $\mathbf{2}$ has the highest calculated detonation velocity within the compounds prepared in this study, and its low melting point and good thermal stability (DSC) make it a suitable candidate for co-melting and casting it with other compounds such as TNT. Further work is underway to assess the performance of these compounds as components of oxygen-balanced mixtures, as well as to study their potential use as plasticizers (compounds 3 and 4) when admixed with diverse secondary explosives.

\section{Experimental}

\section{General}

\section{CAUTION!}

Even though the handling of the reported compounds presented no problems under normal laboratory conditions, one must exercise EXTREME CAUTION and employ standard precautionary measures at all stages of the synthesis, handling, storage, and disposal of EMs. The use of suitable protective gear and equipment is required and strongly encouraged.

Note. All reactions were carried out under normal air atmosphere using oven dried glassware. All chemicals were used as received unless otherwise noted. Reaction solvents were dried by distillation from the appropriate drying agent and stored over $3 \AA$ molecular sieves. All amines were distilled and dried over $3 \AA$ molecular sieves prior to use. The term brine is used to describe a saturated aqueous solution of sodium chloride.

Infrared spectra were recorded as film (neat, liquids and oils) on a Cary 660 Series FTIF Spectrometer with internal calibration. Only the strongest diagnostic bands are reported.

Proton and carbon nuclear magnetic resonance $\left({ }^{1} \mathrm{H}\right.$ NMR, and ${ }^{13} \mathrm{C}$ NMR) spectra were recorded on a Bruker AVANCE-III
$500(500 \mathrm{MHz})$ spectrometer. Unless otherwise stated, $\mathrm{CDCl}_{3}$ was used as solvent. Low and high resolution (LRMS and HRMS) mass spectra were recorded on a Thermo-Electron (DFS) mass spectrometer by electron impact ionization (EI) or chemical ionization (CI). Elemental analyses were performed on a Perkin Elmer PE2400 elemental analyzer by the USAI-UNAM microanalytical laboratory. Melting points were measured with a Thiele-capillary tube system or on a Mettler Toledo DSC1 (STAR 11.0) DSC apparatus and are uncorrected; decomposition temperature and DSC plots were also recorded on this system. Gas Chromatography/Mass Spectroscopy analyses were carried out on a Agilent Technologies 6890 N Network GC System. Thin layer chromatography (TLC) was carried out on commercial aluminum backed silica gel 60 plates (E. Merck, type 5554, $0.2 \mathrm{~mm}$ ). Visualization was accomplished with either UV light $(254 \mathrm{~nm})$, iodine, and/or heating the chromatograms after staining with a solution of phosphomolybdic acid (PMA) in ethanol (20\% w/v, Aldrich), a solution of ammonium molybdate and cerium sulfate in $10 \%$ sulfuric acid $(5 \% \mathrm{w} / \mathrm{v}$ ammonium molybdate and $\left.0.1 \% \mathrm{w} / \mathrm{Ce}(\mathrm{SO})_{4}\right)$, or a solution of $p$-anisaldehyde in a sulfuric acid-EtOH mixture $(5 \% \mathrm{v} / \mathrm{v}$ anisaldehyde and $5 \%$ $\mathrm{v} / \mathrm{v}$ sulfuric acid). Flash chromatography was performed on 230-400 mesh silica gel (Siliaflash ${ }^{\circledR} 60$ Silica Gel). The terms in vacuo or "under reduced pressure" are used to describe removal of solvent using a rotary evaporator.

[1, 3-bis(3,5-dinitrobenzoyloxy)]-2, 2-bis(3, 5-dinitrobenzoy loxymethyl)propane (1). To a stirred solution of 3,5-dinitrobenzoyl chloride (4.124 g, $17.930 \mathrm{mmol})$ in $12 \mathrm{~mL}$ dichloromethane cooled by a ice-water bath, was slowly added a suspension of pentaerythritol $(0.500 \mathrm{~g}, 3.677 \mathrm{mmol})$, triethylamine (1.859 g, $18.367 \mathrm{mmol}$ ), and DMAP ( $0.023 \mathrm{~g}, 0.188 \mathrm{mmol})$. Following addition the ice/water bath was removed and the mixture was refluxed for $16 \mathrm{~h}$. The mixture was then cooled to room temperature and stirred vigorously while $10 \mathrm{~mL}$ of hexane was added. The resulting solid mass was filtered and washed successively with $50 \mathrm{~mL}$ of water, $25 \mathrm{~mL}$ of saturated $\mathrm{NaHCO}_{3}$ solution, $50 \mathrm{~mL}$ water, and $50 \mathrm{~mL}$ of acetone. The resulting material was vacuum-dried to give compound 1 (2.807 g, $77 \%$ yield) as a white amorphous solid, mp $224-225^{\circ} \mathrm{C}$ (dec.), soluble in DMF and DMSO, slightly soluble in acetone, and insoluble in hexane, ethyl acetate, dichloromethane and 95\% ethanol. IR (neat) $v_{\max }: 3096,1725,1539,1343,1266,1156$, $718 \mathrm{~cm}^{-1} ;{ }^{1} \mathrm{H} \mathrm{NMR}\left(\mathrm{CDCl}_{3}, 500 \mathrm{MHz}\right) \delta 9.02(\mathrm{t}, J=2.5 \mathrm{~Hz}, 4 \mathrm{H})$, $8.94(\mathrm{~d}, J=2.5 \mathrm{~Hz}, 8 \mathrm{H}), 4.46(\mathrm{~s}, 8 \mathrm{H}) \mathrm{ppm} ;{ }^{13} \mathrm{C} \mathrm{NMR}\left(\mathrm{CDCl}_{3}\right.$, $125 \mathrm{MHz}) \Delta$ 162.3, 148.3, 132.2, 128.8, 122.5, 64.5, 42.8 ppm; HRMS (m/z) (M-16; $\left.\mathrm{C}_{33} \mathrm{H}_{20} \mathrm{O}_{23} \mathrm{~N}_{8}\right)$ Calc: 896.0636, Found: 896.0642 .

3-(nitroxy)-2, 2-bis[(nitrooxy)methyl]propyl chloroacetate (7). To a cold $\left(0{ }^{\circ} \mathrm{C}\right)$ stirred solution of chloroacetyl chloride (2.55 g, $22.578 \mathrm{mmol})$ in $\mathrm{CH}_{2} \mathrm{Cl}_{2}(30 \mathrm{~mL})$, was added a previously prepared solution of pentaerythritol trinitrate (PETRIN; $2 \mathrm{~g}, 7.376 \mathrm{mmol})$, triethylamine $(2.61 \mathrm{~g}, 25.828 \mathrm{mmol})$, and DMAP $(0.10 \mathrm{~g}, 0.818 \mathrm{mmol})$ in $15 \mathrm{~mL} \mathrm{CH}_{2} \mathrm{Cl}_{2}$. The mixture was allowed to warm to room temperature and then refluxed for $1 \mathrm{~h}$, then cooled to room temperature and stirred for $2 \mathrm{~h}$, and finally quenched with $1 \mathrm{~mL}$ of isopropanol. While stirring the mixture 
$30 \mathrm{~mL}$ of hexane was added to the contents and then filtered through a short plug of Florisil ${ }^{\mathbb{R}}$, eluting with a $1: 1_{\mathrm{v}}$ mixture of hexane and ethyl acetate (AcOEt). After filtration the solvent was removed under reduced pressure and purified by column chromatography (hexane/AcOEt; 9:1 to 1:1) to give compound 7 as a pale yellow oil ( $2.40 \mathrm{~g}, 94 \%$ yield based on PETRIN). IR (neat) $v_{\max } 2965,2909,1752,1632,1270,1162,994,839 \mathrm{~cm}^{-1}$ ; ${ }^{1} \mathrm{H}$ NMR $\left(\mathrm{CDCl}_{3}, 500 \mathrm{MHz}\right) \delta 4.60$ (s, 6H), 4.33 (s, 2H), 4.13 (s, 2H) ppm; ${ }^{13} \mathrm{C}$ NMR $\left(\mathrm{CDCl}_{3}, 125 \mathrm{MHz}\right) \delta 166.3,68.9,62.9$, 42.1, 40.1; GCMS (m/z): 149, 107, 93, 77, 49.

3-(nitrooxy)-2, 2-bis[(nitrooxy)methyl]propyl azidoacetate (2). To a flask charged with acetonitrile $(5 \mathrm{~mL})$ was added sodium azide $(0.194 \mathrm{~g}, 2.985 \mathrm{mmol})$ and potassium iodide $(0.033 \mathrm{~g}$, $0.199 \mathrm{mmol}$ ) while stirring. A solution of the chloroacetate 7 in $3.5 \mathrm{~mL}$ acetonitrile was then added at room temperature. Finally the mixture was heated to $60{ }^{\circ} \mathrm{C}$ and stirred for $2 \mathrm{~h}$, before being allowed to cool to room temperature. Water (30 $\mathrm{mL})$ was added and the mixture extracted with AcOEt $(3 \times 50$ $\mathrm{mL}$ ). The collected organic fractions are washed with brine and dried with anhydrous sodium sulfate. The crude oil was then purified by Flash column chromatography eluting with $\mathrm{CH}_{2} \mathrm{Cl}_{2}$ / $\mathrm{Et}_{2} \mathrm{O} /$ hexane $\left(1: 1: 2_{\mathrm{v}}\right)$ yielding azide $2(0.654 \mathrm{~g}, 93 \%$ yield $)$ as a pale yellow oil. DSC (heating rate: $5^{\circ} \mathrm{C} \mathrm{min}-1$ ): $\mathrm{mp}: 40.6{ }^{\circ} \mathrm{C}$; $197.5^{\circ} \mathrm{C}$ (dec.); IR (neat) $v_{\max }: 2964,2911,2111,1752,1633$, $1269,1167,994,839 \mathrm{~cm}^{-1} ;{ }^{1} \mathrm{H}$ NMR $\left(\mathrm{CDCl}_{3}, 500 \mathrm{MHz}\right) \delta 4.60$ (s, 6H), 4.33 (s, 2H), 4.11 (s, 2H) ppm; ${ }^{13} \mathrm{C}$ NMR $\left(\mathrm{CDCl}_{3}, 500\right.$ MHz) $\delta 166.5,69.1,62.9,42.0,40.2$ ppm; GCMS (m/z): 149, 107, 91, 77, 49. Anal. C 24.22\%, H 2.86\%, N 21.63\%, calcd for $\mathrm{C}_{7} \mathrm{H}_{10} \mathrm{~N}_{6} \mathrm{O}_{11}, \mathrm{C} 23.74 \%, \mathrm{H} 2.85 \%, \mathrm{~N} 23.73 \%$.

[(2-chloroacetyl)imino]diethane-2, 1-diyl bis(chloroacetate) (11): To a cooled (ice-water bath) solution of chloroacetyl chloride (CAC; $16.023 \mathrm{~g}, 0.142 \mathrm{~mol})$ in $\mathrm{CH}_{2} \mathrm{Cl}_{2}(100 \mathrm{~mL}$ ) was added drop wise while stirring a solution of diethanolamine $(5 \mathrm{~g}$, $0.048 \mathrm{~mol})$, triethylamine $(14.883 \mathrm{~g}, 0.147 \mathrm{~mol})$, and DMAP $(0.29 \mathrm{~g}, 0.002 \mathrm{~mol})$ in $\mathrm{CH}_{2} \mathrm{Cl}_{2}(30 \mathrm{~mL})$. Immediately after the addition was complete the ice-water bath was removed and the reaction mixture was allowed to warm up to room temperature and was stirred for $3 \mathrm{~h}$. To the stirred reaction mixture was then added successively water $(150 \mathrm{~mL})$ and a saturated solution of $\mathrm{NaHCO}_{3}(20 \mathrm{~mL})$. The organic phase was separated from the aqueous solution and a further extraction of the solution was carried out with $\mathrm{CH}_{2} \mathrm{Cl}_{2}(100 \mathrm{~mL})$. The organic phases were combined and washed with brine, followed by drying with anhydrous $\mathrm{Na}_{2} \mathrm{SO}_{4}$. The solvent was then removed under reduced pressure. The resulting crude brown oil was then subjected to Flash column chromatography eluting with hexane/AcOEt (2:1 to 1:2). Collection of the appropriate fractions and removal of the solvent under reduced pressure and further high vacuum treatment ( $2 \mathrm{~h}, 90$ torr) provided trichloride $\mathbf{1 1}$ as a light brown oil (13.255 g, 83\% yield) IR(neat) $v_{\max } 2961,1743,1652,1424$, $1284,1168,1020,779 \mathrm{~cm}^{-1} ;{ }^{1} \mathrm{H}$ NMR $\left(\mathrm{CDCl}_{3}, 500 \mathrm{MHz}\right) \delta 4.36$ (t, $J=5 \mathrm{~Hz}, 4 \mathrm{H}), 4.17(\mathrm{~s}, 2 \mathrm{H}), 4.09(\mathrm{~s}, 2 \mathrm{H}), 4.06(\mathrm{~s}, 2 \mathrm{H}), 3.75$ (t, $J=5 \mathrm{~Hz}, 2 \mathrm{H}), 3.67(\mathrm{t}, J=5 \mathrm{~Hz}, 2 \mathrm{H}) ;{ }^{13} \mathrm{C}$ NMR $\left(\mathrm{CDCl}_{3}, 125\right.$ MHz) $\delta 167.4,167.12,167.0,63.2,47.3,45.5,41.0,40.7,40.5$. Anal. C $37.09 \%, \mathrm{H} 4.31 \%, \mathrm{~N} 4.51 \%$, calcd., for $\mathrm{C}_{11} \mathrm{H}_{16} \mathrm{Cl}_{3} \mathrm{NO}_{5}$, C $37.90 \%, \mathrm{H} 4.63 \%$, N $4.02 \%$.
[2-(2 $\lambda^{5}$-triaz-1-en-2-yn-1-yl)acetyl]imino]diethane-2, 1-diyl bis(2 $\lambda^{5}$-triaz-1-en-2-yn-1-ylacetate) (3). To a stirred solution of trichloride $11(1 \mathrm{~g}, 4.386 \mathrm{mmol})$ and acetonitrile $(8 \mathrm{~mL})$ was added at room temperature sodium azide $(1.14 \mathrm{~g}, 17.538 \mathrm{mmol})$ and potassium iodide $(0.146 \mathrm{~g}, 0.880 \mathrm{mmol})$. The mixture was warmed up to $60{ }^{\circ} \mathrm{C}$ and stirred for $16 \mathrm{~h}$. After gradually allowing cooling to room temperature, water $(50 \mathrm{~mL})$ was added and the mixture was extracted with AcOEt $(3 \times 50 \mathrm{~mL})$. The collected organic fractions were washed with brine and dried with anhydrous sodium sulfate. The crude oil thus obtained was purified by Flash column chromatography, eluting with hexane/AcOEt $\left(1: 1_{\mathrm{v}}\right)$ to give triazide $3(1.006 \mathrm{~g}, 95 \%)$ as a pale yellow oil; IR(neat): 2950, 2099, 1742, 1653, 1438, 1273, 1184, $1017,564 \mathrm{~cm}^{-1} ;{ }^{1} \mathrm{H}$ NMR $\left(\mathrm{CDCl}_{3}, 500 \mathrm{MHz}\right) \delta 4.37$ (t, $J=10$ $\mathrm{Hz}, 2 \mathrm{H}), 4.32$ (t, $J=10 \mathrm{~Hz}, 2 \mathrm{H}), 3.99(\mathrm{~s}, 2 \mathrm{H}), 3.94$ (s, 2H), 3.89 (s, 2H), 3.68 (t, $J=5 \mathrm{~Hz}, 2 \mathrm{H}), 3.60(\mathrm{t}, J=5 \mathrm{~Hz}, 2 \mathrm{H}) ;{ }^{13} \mathrm{C} \mathrm{NMR}$ $\left(\mathrm{CDCl}_{3}, 125 \mathrm{MHz}\right): \delta 168.2,168.1,62.9,62.6,50.3,46.5,45.6$. Anal. C $33.95 \%, \mathrm{H} 3.89 \%$, N $36.18 \%$, calcd for $\mathrm{C}_{10} \mathrm{H}_{14} \mathrm{~N}_{10} \mathrm{O}_{5}$, C $33.90 \%$, H $3.98 \%$, N 39.54\%.

2-[(dichloroacetyl)amino]-1-(4-nitrophenyl)propane-1, 3diyl dinitrate (4). To a cooled $\left(0^{\circ} \mathrm{C}\right)$, vigorously stirred mixture of $66 \%$ nitric acid $(30 \mathrm{~mL})$, ammonium nitrate $(5 \mathrm{~g}, 0.063 \mathrm{~mol})$, and $98 \%$ sulfuric acid $(40 \mathrm{~mL})$, was added finely powdered chloramphenicol $(\mathbf{1 2}, 7.5 \mathrm{~g}, 0.023 \mathrm{~mol})$, followed by addition of $\mathrm{CH}_{2} \mathrm{Cl}_{2}(100 \mathrm{~mL})$. The reaction mixture was then warmed to room temperature and stirred for $30 \mathrm{~min}$; then the contents were transferred to a separation funnel and the organic (upper) phase was separated and washed with water $(2 \times 100 \mathrm{~mL})$, $10 \%$ sodium bicarbonate solution $(30 \mathrm{~mL})$ and brine $(60 \mathrm{~mL})$, followed by drying with anhydrous sodium sulfate. Meanwhile, the remaining acidic phase was placed in the original reaction flask and to it was added $\mathrm{CH}_{2} \mathrm{Cl}_{2}(70 \mathrm{~mL})$ and the mixture was vigorously stirred at room temperature for $30 \mathrm{~min}$. Then the phases were separated and the organic phase was subjected to the same washing and drying procedure as mentioned above for the first fraction. Then the two washed and dried organic fractions were combined and the solvent was removed in vacuo (rotavapor, followed by vacuum pump - 90 torr). Thin layer chromatography showed only one spot ( $\mathrm{Rf} 0.4$, hexane/AcOEt $4: 1$; UV) for the resulting pale yellow viscous oil corresponding to compound $4(9.522 \mathrm{~g}, 99 \%)$. IR (neat) $v_{\max } 3392,3286,2912$, $1642,1522,1350,1272,1004,824 \mathrm{~cm}^{-1} ;{ }^{1} \mathrm{H}$ NMR $\left(\mathrm{CDCl}_{3}, 500\right.$ MHz) $\delta 8.31(\mathrm{dm}, J=10 \mathrm{~Hz}, 2 \mathrm{H}), 7.63(\mathrm{dm}, J=10 \mathrm{~Hz}, 2 \mathrm{H}), 6.91$ $(\mathrm{d}, J=10 \mathrm{~Hz}, 1 \mathrm{H}), 6.20(\mathrm{~d}, J=5 \mathrm{~Hz}, 1 \mathrm{H}), 5.90(\mathrm{~s}, 1 \mathrm{H}), 4.82-$ $4.75(\mathrm{~m}, 1 \mathrm{H}), 4.72(\mathrm{dd}, J=15,5 \mathrm{~Hz}, 1 \mathrm{H}), 4.54$ (dd, $J=15,5 \mathrm{~Hz}$, $1 \mathrm{H}) ;{ }^{13} \mathrm{C} \mathrm{NMR}\left(\mathrm{CDCl}_{3}, 125 \mathrm{MHz}\right) \delta 164.5,148.7,140.4,127.5$, 124.5, 80.5, 69.5, 65.7, 60.6; GCMS (m/z): 151, 150, 105, 104, $92,77,65,51$. Anal. C $31.3 \%$, H $2.78 \%$, N $13.09 \%$, calcd for $\mathrm{C}_{11} \mathrm{H}_{10} \mathrm{Cl}_{2} \mathrm{~N}_{4} \mathrm{O}_{9}$, C $31.98 \%$, H 2.44\%, N 13.56\%.

\section{Acknowledgements}

Technical assistance from M.Sc. Julio C. Cortés, M.Sc. Atilano Gutiérrez Carrillo, and proofreading of the manuscript by Prof. Elizabeth A. Lund is gratefully acknowledged. 


\section{References}

1. Gash, A.; Thadhani, N.N.; Wilson, W.H.; Armstrong, R.W.; Munir, Z.A. Co-Organizers: Multifunctional Energetic Materials, Materials Research Society (MRS) Symposium H, November 28-30, Boston, MA. 2005

2. Hazen, R.M. The Diamond Makers; Chap. 11, The New Diamond Makers: Diamonds by Explosion, pp.190-198; Cambridge University Press, 1999.

3. Wu, M-H.; Lu,T-H. J. Micromech. Microeng. 2012, 22, 105040

4. a) Agrawal, J.P. High Energy Materials. Propellants, Explosives and Pyrotechnics. Wiley-VCH, 2010; b) Agrawal, J.P.; Hodgson, R.D. Organic Chemistry of Explosives. John Wiley \& Sons, Ltd, 2007; c) Klapötke, T.M.; Chemistry of High-Energy Materials, $2^{\text {nd }}$. Ed., Walter de Gruyter GmbH \& Co. KG, Berlin/Boston, 2012.

5. Shriner, R.L.; Hermann, C.K.F.; Morrill, T.C.; Curtin, D.Y.; Fuson, R.C. The Systematic Identification of Organic Compounds, $8^{\text {th }}$. Ed. Wiley \& Sons, Inc., 2004.

6. a) Keshavarz, M.H.; Pouretedal, H.R. Prop. Explos. Pyrotech. 2005, 30(2), 105-108; b) Rothstein, L.P.; Petersen, R. Prop. Explos. Pyrotech. 1979, 4, 56-60; c) Rothstein, L.P.; Petersen, R. Prop. Explos. Pyrotech. 1981, 6, 91-93; d) Willer, R.L. J. Mex. Chem. Soc. 2009, 53(3), 108-119.

7. Advanced Chemistry Development, Inc.; http://www.chemspider. com/ACDLabs.aspx (Aug., 2013)

8. A) Heisler, R.V.; McEwen, W.E.; Vander Werf., C.A. J. Am. Chem. Soc. 1954, 76, 1231; b) Frankel, M.B.; Witucki, E.F. J. Chem. Eng. Data 1979, 24, 247; c) Frankel, M.B.; Witucki, E.F. J.
Chem. Eng. Data 1982, 27, 94; d) Boren, C.; Jisheng, L.; Naixing, W.; Yuxiang, O.; Propell. Explos. Pyrotech. 1998, 23, 46; e) Bau, R.; Olah, G.A.; Surya Prakash, G.K.; Schreiber, A.; Struckhoff, Jr, J.J.; Weber K. J. Org. Chem. 1997, 62, 1872.

9. a) Drees, D.; Löffel, D.; Messmer, A., Schmid, K.; Propell. Explos. Pyrotech. 1999, 24, 159-162.; b) Provatas, A.; Energetic Polymers and Plasticisers for Explosive Formulations - A Review of Recent Advances; Weapons Systems Division, Aeronautical and Maritime Research Laboratory, DSTO-TR-0966, pp.26-27, April 2000

10. Ref. 4c, p.237.

11. Camp, A.T.; Marans, N.S.; Elrick, D.E.; Preckel, R.F. J. Am. Chem. Soc. 1955, 77(3), 751-752.

12. Koenig, A.; Lange, K.; Konter, J.; Daiber, A.; Stalleicken, D.; Glusa, E.; Lehmann, J. J. Cardiovasc. Pharmachol. 2007, 50, 6874.

13. Lee, J-S; Hsu, C-K; Chang, C-L. Thermochimica Acta 2002, 392393, 173-176.

14. Akhavan, J. The Chemistry of Explosives, $3^{\text {rd }}$. Ed., RSC Publishing, 2011.

15. a) Urbański, T. Chemistry and Technology of Explosives, Vol. 3, Pergamon Press, Oxford, 36-37 (1967); b) Ref. 4b, p. 335, and references cited therein.

16. Smith, P.A.S. Open-Chain Nitrogen Compounds, Bd. 2, Benjamin, New York, pp. 211-256 (1966)

17. The Merck Manual for Health Care Professionals, www.merckmanuals.com/ professional/ infectious_diseases/bacteria_and_antibacterial_drugs/chloramphenicol.html (Aug., 2013). 